\title{
ZnTe Semiconductor-Polymer Gel Composited Electrolyte for Conversion of Solar Energy
}

\author{
Wonchai Promnopas, ${ }^{1}$ Titipun Thongtem, ${ }^{2,3}$ and Somchai Thongtem ${ }^{1,3}$ \\ ${ }^{1}$ Department of Physics and Materials Science, Faculty of Science, Chiang Mai University, Chiang Mai 50200, Thailand \\ ${ }^{2}$ Department of Chemistry, Faculty of Science, Chiang Mai University, Chiang Mai 50200, Thailand \\ ${ }^{3}$ Materials Science Research Center, Faculty of Science, Chiang Mai University, Chiang Mai 50200, Thailand
}

Correspondence should be addressed to Wonchai Promnopas; wonchaicmu@gmail.com and Somchai Thongtem; schthongtem@yahoo.com

Received 22 May 2013; Accepted 17 September 2013; Published 8 January 2014

Academic Editor: Christopher L. Kitchens

Copyright (C) 2014 Wonchai Promnopas et al. This is an open access article distributed under the Creative Commons Attribution License, which permits unrestricted use, distribution, and reproduction in any medium, provided the original work is properly cited.

\begin{abstract}
Nanostructured cubic p-type ZnTe for dye sensitized solar cells (DSSCs) was synthesized from 1:1 molar ratio of Zn: Te by $600 \mathrm{~W}$ and $900 \mathrm{~W}$ microwave plasma for $30 \mathrm{~min}$. In this research, their green emissions were detected at the same wavelengths of $563 \mathrm{~nm}$, the energy gap $\left(E_{g}\right)$ at $2.24 \mathrm{eV}$, and three Raman shifts at 205, 410, and $620 \mathrm{~cm}^{-1}$. The nanocomposited electrolyte of quasisolid state $\mathrm{ZnO}-\mathrm{DSSC}$ was in correlation with the increase in the $J_{\mathrm{SC}}, V_{\mathrm{OC}}$, fill factor (ff), and efficiency ( $\eta$ ) by increasing the wt\% of ZnTeGPE (gel polymer electrolyte) to an optimum value and decreased afterwards. The optimal ZnO-DSSC performance was achieved for $0.20 \mathrm{wt} \% \mathrm{ZnTe}-\mathrm{GPE}$ with the highest photoelectronic energy conversion efficiency at $174.7 \%$ with respect to that of the GPE without doping of p-type ZnTe.
\end{abstract}

\section{Introduction}

Since the first report on low-cost dye sensitized solar cells (DSSCs) in 1991 [1], great efforts have been made to improve their performance [2-4]. In spite of their initial success of approximately $11 \%$ solar energy conversion efficiency, much effort to improve cell performance has not been made to major breakthrough since then [5]. DSSCs are very attractive and promising alternative for the development of new generation of photovoltaic devices. Recent research has focused on the use of p-type semiconductors and organic hole-transport materials [6-9] that have better mechanical properties and simple fabrication processes. The main difficulty is to form contacts at p-n junctions and the potential of DSSCs using solid state electrolyte is quite low [10]. Thus, both liquid and solid electrolytes are combined to form quasisolid (gel) electrolytes, including the replacement of liquid electrolytes by solid state hole conductors such as p-type semiconductors [11], $\mathrm{CuI}[12], \mathrm{CuSCN}[13,14]$, and $\mathrm{NiO}$ [15-17] and polymeric electrolytes $[18,19]$. In this study, p-type ZnTe as hole collectors in a polymer electrolyte was used to fabricate solid state DSSCs.

\section{Experimental Procedures}

2.1. p-Type ZnTe. To synthesize ZnTe, Zn and Te powders (analytical grade, Fluka) were used without further purification. Four mixtures of 1:1 molar ratio $\mathrm{Zn}$ : Te were mixed by rotation for $1 \mathrm{~h}$ at room temperature and loaded into $11 \mathrm{~mm}$ I.D. $\times 100 \mathrm{~mm}$ long silica boats. Each was placed in a horizontal quartz (HQ) tube at a time. The HQ tube was tightly closed and evacuated to $4.3 \pm 1 \mathrm{kPa}$ absolute pressure for removal of air and followed by gradual feeding of argon into this HQ tube. The procedure was repeated three times. Finally, argon in the HQ tube was evacuated to $4.3 \pm 1 \mathrm{kPa}$ constant absolute pressure. Each solid mixture was heated in a manner of $10 \mathrm{~min}$ batch run by a $2,450 \mathrm{MHz}$ microwave plasma using 300,450 , 600 , and $900 \mathrm{~W}$, left to cool down in vacuum to room temperature, and thoroughly mixed. The process was repeated under the same condition until $30 \mathrm{~min}$ run completion. In the end, the products were collected for further characterization and for being selected for fabrication of DSSCs.

2.2. Gel Polymer Electrolyte. Basically, gel polymer electrolyte (GPE) contained $0.10,0.20,0.30,0.40,0.50$, and $0.70 \mathrm{wt} \%$ 


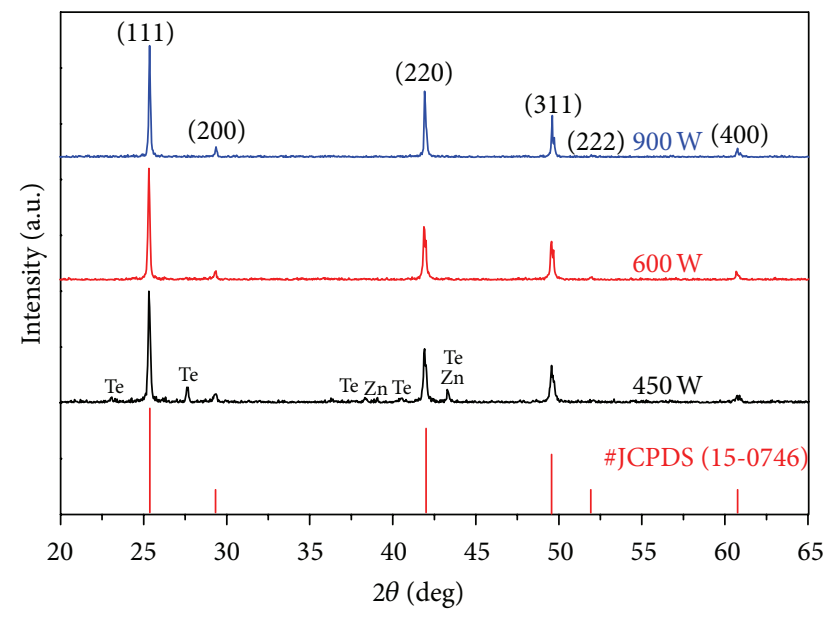

Figure 1: XRD patterns of ZnTe synthesized by 450, 600, and $900 \mathrm{~W}$ microwave plasma for $30 \mathrm{~min}$.

p-type ZnTe in electrolytic solution of $0.5 \mathrm{mM}$ LiI, $0.05 \mathrm{mM}$ I, $0.15 \mathrm{nM}$ PEG20000, and $10 \mathrm{~mL}$ acetonitrile $\left(\mathrm{CH}_{3} \mathrm{CN}\right)$. The colloidal liquid was stirred at $60^{\circ} \mathrm{C}$ for $30 \mathrm{~min}$ until clear homogeneous quasisolid state was achieved.

2.3. Fabrication of DSSCs. $\mathrm{ZnO}$ films were deposited on two fluorine-doped tin oxide (FTO) glass plates by the microwave plasma technique. Each of $\mathrm{ZnO}$ photoelectrodes was soaked in the Eosin Y dye (the cheapest dye) solution for $24 \mathrm{~h}$ and dried. Concurrently, the FTO electrode was coated by platisol T solution until its sheet resistance was achieved at $10 \Omega / \mathrm{cm}^{2}$. The GPE solution was cast on the dye-absorbed glass plate and the counter electrode over $1 \mathrm{~cm}^{2}$ in area for fabrication of a solar cell. Then, the photoanode was partly placed on top of the counter electrode such that they were extended beyond, with the GPE sandwiched in between them. This solar cell was tightly held together by alligator clips. Each sandwichtype photoelectrochemical solar cell was composed of a dyeabsorbed $\mathrm{ZnO}$ photoelectrode with $8 \mathrm{~mm}$ in thickness, a laminar film, and a counter electrode.

\section{Results and Discussion}

3.1. $X R D$. $X R D$ is an effective method for determining phases and crystallite sizes of the as-synthesized products. XRD patterns (Figure 1) of the products synthesized by different powers of microwave were characterized. All the spectra were compared with the JCPDS database (reference codes: 15-0746 for ZnTe, 01-1238 for Zn, and 01-0714 for Te) [20]. At $300 \mathrm{~W}$ (result not shown), the product was composed of ZnTe and some impurities. Upon increasing the heating power from $300 \mathrm{~W}$ to 450,600 , and $900 \mathrm{~W}$, the reactions of $\mathrm{Zn}$ and Te became more complete with reduction in impurities. At $450 \mathrm{~W}, \mathrm{Zn}$ and Te impurities were still left in the main product. At 600 and $900 \mathrm{~W}$, only cubic ZnTe was detected with no impurity detection. At these stages, the chemical reaction of $\mathrm{Zn}$ and $\mathrm{Te}$ was complete. Comparing among different heating powers, the XRD peaks at $900 \mathrm{~W}$ were the sharpest, implying that this product was the best crystalline and that its atoms resided in normal lattice. The strongest intensity peak is at $2 \theta$ of 25.3 degrees and diffracted from the (111) crystallographic planes of the cubic ZnTe main product.

Generally, reaction rate is controlled by heating power and temperature. Therefore, increasing of the heating power has the influence to increase the driving force of reaction, which promotes the reaction rate to speed up and more product is synthesized. Calculated average crystallite sizes using the Scherrer formula [21] were $51.729 \mathrm{~nm}$ at $600 \mathrm{~W}$ and $51.734 \mathrm{~nm}$ at $900 \mathrm{~W}$, due to the crystal growth process.

3.2. SEM and SAED. SEM image (Figure 2(a)) shows a number of ZnTe nanoparticles oriented in different directions with $50 \mathrm{~nm}$ in diameter at $600 \mathrm{~W}$ microwave heating. This product appears as facet nanoparticles in clusters, specified as crystal-in accordance with the above XRD analysis.

SAED pattern (Figure 2(b)) of the ZnTe product appeared as hollow concentric rings of bright spots, showing that this product was composed of a number of nanocrystals with different orientations. These rings were interpreted and found to correspond very well with the (111), (200), (220), (311), (400), and (511) planes of cubic ZnTe [20].

3.3. Photoluminescence (PL) and UV-Visible Absorption. PL emission of cubic ZnTe (Figure 3(a)) was green emission centered at around $563 \mathrm{~nm}(2.20 \mathrm{eV})$, possibly associated with point defects with their energy level above the valence band edge. The emission was in accordance with green emission centered at $560 \mathrm{~nm}$ wavelength $(2.21 \mathrm{eV})$ of ZnTe nanowires reported by Meng et al. [22], and $552 \mathrm{~nm}$ wavelength $(2.25 \mathrm{eV})$ of $14 \mathrm{~nm}$ nanocrystals reported by Lee et al. [23]. The present emission was slightly red shift comparing to $2.26 \mathrm{eV}$ band gap of ZnTe (bulk) [22] caused by some defects residing in the product.

UV-visible absorption of ZnTe synthesized by the 600 and $900 \mathrm{~W}$ microwave plasma was recorded. The direct energy gap $\left(E_{g}\right)$ was determined by extrapolation the linear portion of the curves (Figure 3(b)) to zero absorbance, corresponding to $2.24 \mathrm{eV}$ for the threshold optical absorption. In this study, the photoluminescence energy is less than the energy gap due to the existence of defects.

3.4. Raman Spectra. Raman spectra (Figure 4) of $\mathrm{ZnTe}$ nanocrystals synthesized by different microwave powers were composed of three longitudinal optical (LO) modes at $205 \mathrm{~cm}^{-1}$ (fundamental), $410 \mathrm{~cm}^{-1}$ (1st overtone), and $620 \mathrm{~cm}^{-1}$ (2nd overtone) and were in good accordance with the available results at $198 \mathrm{~cm}^{-1}$ and $396 \mathrm{~cm}^{-1}$ modes of ZnTe nanowires reported by Meng et al. [22].

3.5. DSSCs. ZnO films were synthesized by the microwave plasma technique for using as photoelectrodes. In general, the operating principle of a DSSC with p-type ZnTe adding in polymer electrolyte is shown in Figure 5. It consisted of a transparent conductive oxide glass (F-doped $\mathrm{SnO}_{2}$ glass, FTO), nanoporous $\mathrm{ZnO}$ layer, Eosin $\mathrm{Y}$ dye (the cheapest dye) monolayer bonded to $\mathrm{ZnO}$ nanoparticles, electrolyte 


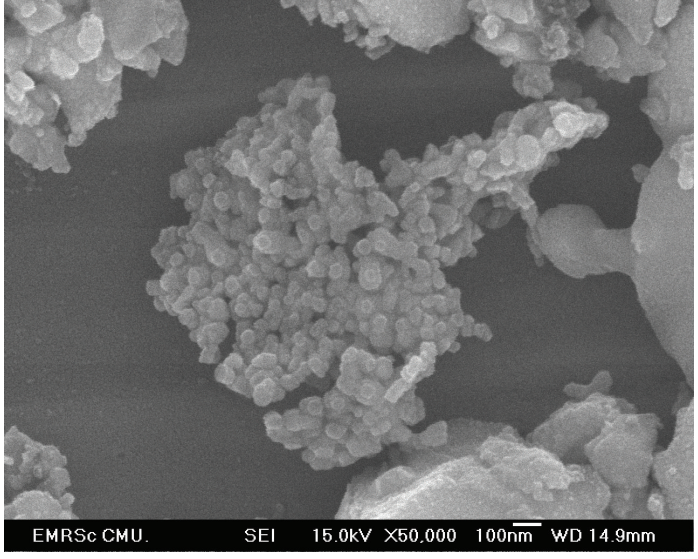

(a)

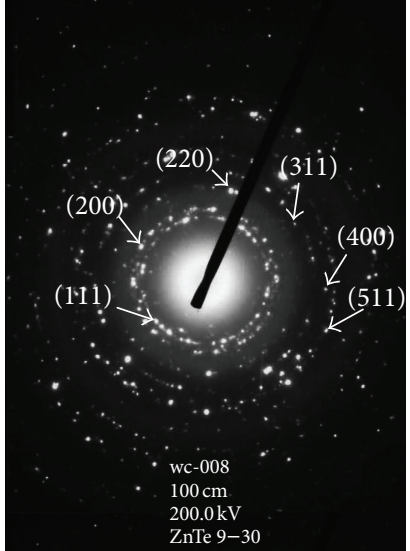

(b)

FIgURE 2: (a) SEM image and (b) SAED pattern of ZnTe synthesized by $600 \mathrm{~W}$ microwave plasma for $30 \mathrm{~min}$.

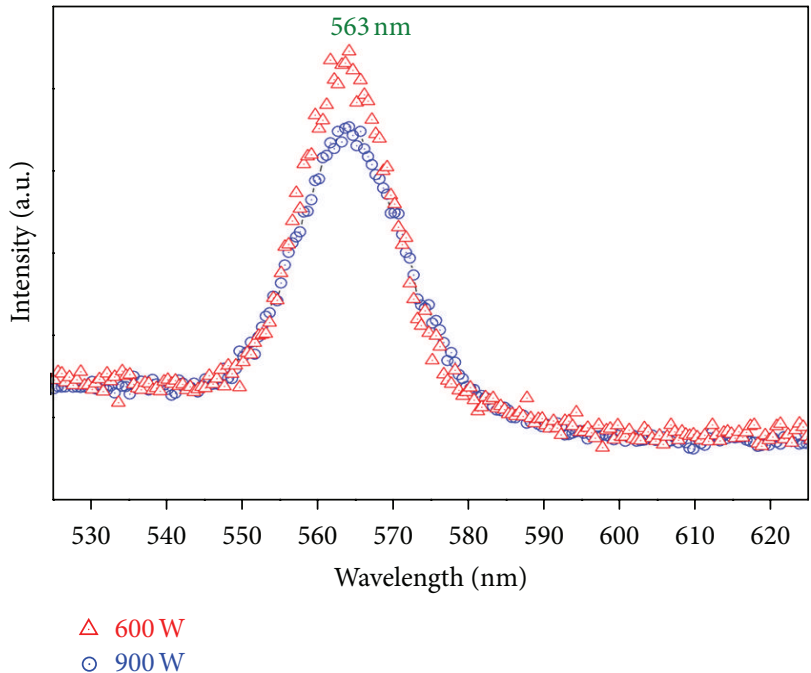

(a)

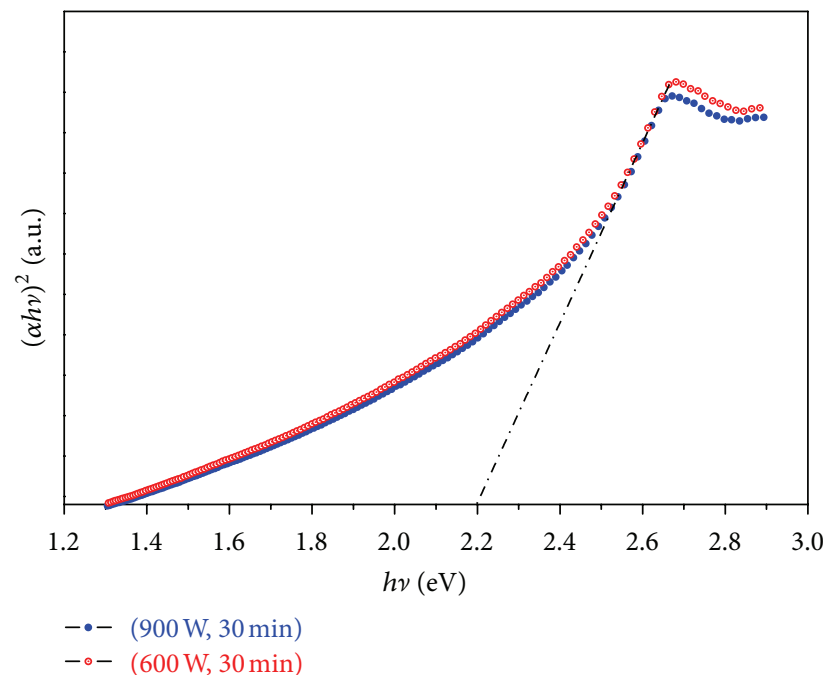

(b)

Figure 3: (a) PL emissions and (b) the $(\alpha h \nu)^{2}$ versus $h \nu$ plots of ZnTe synthesized by the 600 and $900 \mathrm{~W}$ microwave plasma for 30 min.

consisting of $\mathrm{I}^{-}$and $\mathrm{I}_{3}^{-}$redox species, and platinum coated on counter electrode. When the dye sensitizer was excited by solar radiation, electrons were released into conduction band of mesoporous oxide film and further diffused towards the anode and utilized at external loads prior to be collected by the electrolyte at the cathode to complete the cycle. To improve transmittance properties and electrical conductivity, a FTO conducting glass was used as the anode. Zinc oxide thin film deposited on the FTO glass can play the role in the exciton dissertation and the electron diffusion processes. Porosity of the oxide thin film is the important factor that controls the content of absorbed dye molecules and provides surface area of reaction sites on monolayer dye molecules deposited on top. The selection of dye should correspond to the solar energy range, long-term stability, and firm grafting. $\mathrm{I}^{-}$and $\mathrm{I}_{3}{ }^{-}$couples as well as ZnTe-GPE were used, including a platinum catalyst deposited at the cathode [24-26].
The $J-V$ characteristic curves of $0-0.70 \mathrm{wt} \% \mathrm{ZnTe}-\mathrm{GPE}$ DSSCs are shown in Figure 6, including their performance parameters in Table 1 . The efficiency $(\eta)$ was calculated by

$$
\eta(\%)=\frac{J_{\mathrm{SC}} \cdot V_{\mathrm{OC}} \cdot \mathrm{ff}}{P_{\text {in }}} \times 100
$$

where $J_{\mathrm{SC}}, V_{\mathrm{OC}}, \mathrm{ff}$, and $P_{\text {in }}$ are the short-circuit current density, open-circuit voltage, fill factor, and incident light power density, respectively $[24,27-30]$. In this research, the efficiency of the DSSCs increases to the highest value with the increase in wt $\% \mathrm{ZnTe}$ added to GPE and decreases afterwards. For $0.20 \mathrm{wt} \%$ ZnTe-GPE, its efficiency was the highest at $174.7 \%$ with respect to that of the GPE without doping of ptype $\mathrm{ZnTe}$. Comparison with other researchers showed that performance of photovoltaic cells was controlled by several parameters according to the following. Premalal et al. [13] 
TABLE 1: Performance of the DSSCs.

\begin{tabular}{lccccc}
\hline DSSCs & wt $\%$ ZnTe & $J_{\text {sc }}\left(\mathrm{mA} / \mathrm{cm}^{2}\right)$ & $V_{\text {oc }}(\mathrm{V})$ & ff & \\
\hline ZT-000 & 0.00 & 1.113 & 0.476 & 0.343 & 100.0 \\
ZT-001 & 0.10 & 1.631 & 0.487 & 0.274 & 119.8 \\
ZT-002 & 0.20 & 1.635 & 0.508 & 0.383 & 174.7 \\
ZT-003 & 0.30 & 1.510 & 0.512 & 0.402 & 0.363 \\
ZT-004 & 0.40 & 0.893 & 0.465 & 0.306 & 83.0 \\
ZT-005 & 0.50 & 0.539 & 0.476 & 0.130 \\
ZT-007 & 0.70 & 0.077 & 0.349 & 42.9 \\
\hline
\end{tabular}

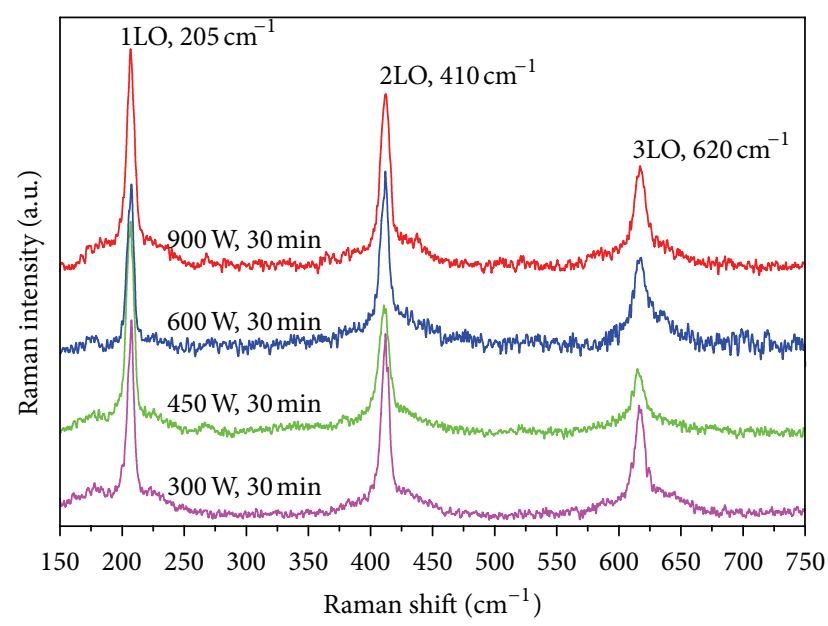

FIGURE 4: Raman spectra of ZnTe synthesized by 300, 450, 600, and $900 \mathrm{~W}$ microwave plasma for $30 \mathrm{~min}$.

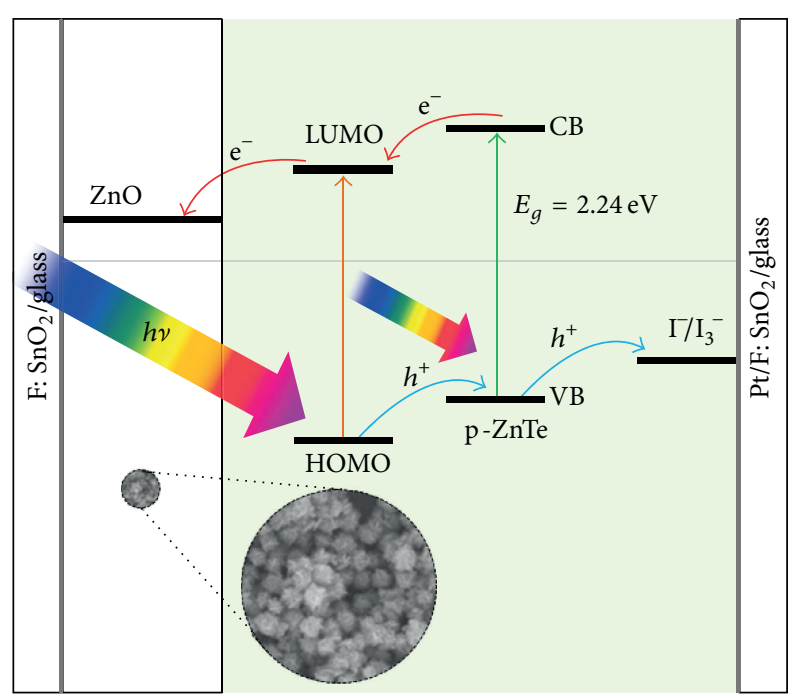

FIGURE 5: A simplified energy level diagram of the ZnTe-GPE DSSCs.

demonstrated the enhancement of conductivity and better pore filing of modified CuSCN inside the $\mathrm{TiO}_{2}$ matrix. The solar cell performance gradually increased to a maximum value beyond which it decreased. For the best results, the

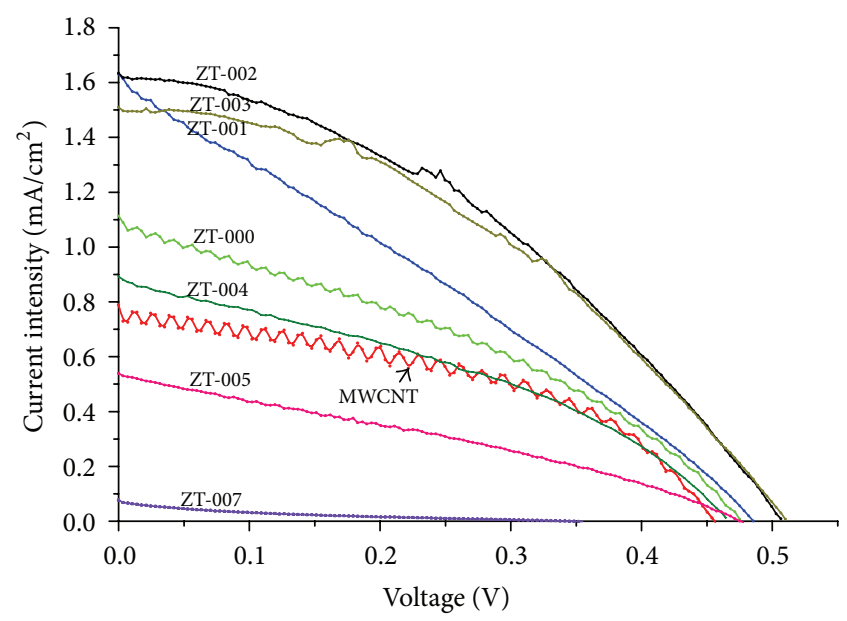

FIGURE 6: $J-V$ characteristic curves of DSSCs with different contents of ZnTe in GPE.

conversion efficiency is $3.4 \%$ at AM 1.5 with $41.8 \%$ enhancement of a solid state DSSC using CuSCN as a hole transport material. It was 14 times higher than that obtained for the solid state DSSC of ordinary CuSCN. Chung et al. [27] found that the fresh and clean $\mathrm{CsSnI}_{3}$ cell showed very good $J-V$ characteristics of solid state solar cell: $J_{\mathrm{SC}}=8.82 \mathrm{~mA} / \mathrm{cm}^{2}$, $V_{\mathrm{OC}}=0.638 \mathrm{~V}, \mathrm{ff}=66.1 \%, \eta=3.72 \%, J_{\mathrm{SC}}=12.2 \mathrm{~mA} / \mathrm{cm}^{2}$, and $\eta=5.62 \%$ by doping with $5 \mathrm{~mol} \%$ fluorine. Further improvement was obtained for $2 \mathrm{~mol}^{2} \mathrm{SnF}_{2}-\mathrm{CsSnI}_{2.95} \mathrm{~F}_{0.05}$ which, respectively, provided an increase in $29 \%$ and $21 \%$ of $J_{\mathrm{SC}}\left(15.7 \mathrm{~mA} / \mathrm{cm}^{2}\right)$ and $\eta(6.81 \%)$ comparing to the undoped CsSnI $2.95 \mathrm{~F}_{0.05}$ with the optimum molar concentration of $5 \mathrm{~mol} \% \mathrm{SnF}_{2}$. Similarly, the $\mathrm{TiO}_{2}$ nanoporous film of the corresponding cell was pretreated by a fluorine plasma etching process to increase the size of the nanopores and nanochannels, including the possibility to reduce surface states and charged particle recombination. The results were $J_{\mathrm{SC}}=17.4 \mathrm{~mA} / \mathrm{cm}^{2}, V_{\mathrm{OC}}=0.730 \mathrm{~V}$, ff $=72.9 \%$, and $\eta=9.28 \%$. Kim et al. [31] fabricated a DSSC using titanium deposited with a dye-absorbed $\mathrm{TiO}_{2}$ layer as a working electrode and a platinum deposited with a porous polymer electrolyte membrane as a counter electrode. Overall, the ionic conductivity was improved by increasing the P123 content. The photoelectrochemical characteristics were also controlled by the thickness of the $\mathrm{TiO}_{2}$ layer and the twist pitch length of the counter electrode. The best performance 
is $J_{\mathrm{SC}}=2.117 \mathrm{~mA} / \mathrm{cm}^{2}, V_{\mathrm{OC}}=0.6932 \mathrm{~V}$, ff $=0.7015$, and $\eta=1.029 \%$. Kumara et al. [32] found that the thickness of $\mathrm{TiO}_{2}$ and $\mathrm{ZnO}$ layers can play the role in conversion efficiency of the photovoltaic cells. When the thickness and, hence, the sheet resistance of the $\mathrm{TiO}_{2}$ dense layer were increased, the conversion efficiency was gradually increased up to $2.6 \%$ at a sheet resistance of $370 \Omega$ (15 $\mu \mathrm{m}$ thick) beyond which it decreased. Upon the use of $\mathrm{ZnO}$ dense layer for the replacement of $\mathrm{TiO}_{2}$ dense layer, the similar trend was also detected, and the best conversion efficiency of $3.2 \%$ was obtained at a sheet resistance of $2500 \Omega(15 \mu \mathrm{m}$ thick $)$.

\section{Conclusions}

Pure cubic ZnTe nanocrystals were successfully synthesized by an inexpensive solid state process using 600 and $900 \mathrm{~W}$ microwave plasma for $30 \mathrm{~min}$. Their photoluminescence was the same green emission centered at $563 \mathrm{~nm}(2.20 \mathrm{eV})$, possibly associated with point defect level above the valence band edge. The performance of quasisolid state $\mathrm{ZnO}$ DSSCs with different wt\% ZnTe-GPE composited electrolytes was the highest efficiency for $0.20 \mathrm{wt} \% \mathrm{ZnTe}$ adding.

\section{Conflict of Interests}

The authors declare that there is no conflict of interests regarding the publication of this paper.

\section{Acknowledgments}

The authors wish to thank the National Nanotechnology Center (NANOTEC) and the National Science and Technology Development Agency (NSTDA), for providing financial support through the Project P-10-11345, and the Thailand's Office of the Higher Education Commission for providing financial support through the National Research University (NRU) Project for Chiang Mai University.

\section{References}

[1] B. O’Regan and M. Grätzel, "A low-cost, high-efficiency solar cell based on sensitized colloidal $\mathrm{TiO}_{2}$ films," Nature, vol. 353, pp. 737-740, 1991.

[2] M. Grätzel, "Photoelectrochemical cells," Nature, vol. 414, pp. 338-344, 2001.

[3] M. Grätzel, "Dye-sensitized solar cells," Journal of Photochemistry and Photobiology C, vol. 4, no. 2, pp. 145-153, 2003.

[4] M. Grätzel, "Conversion of sunlight to electric power by nanocrystalline dye-sensitized solar cells," Journal of Photochemistry and Photobiology A, vol. 164, no. 1-3, pp. 3-14, 2004.

[5] A. Hagfeldt, G. Boschloo, L. Sun, L. Kloo, and H. Pettersson, "Dye-sensitized solar cells," Chemical Reviews, vol. 110, no. 11, pp. 6595-6663, 2010.

[6] B. O’Regan, F. Lenzmann, R. Muis, and J. Wienke, "A solid-state dye-sensitized solar cell fabricated with pressure-treated P25$\mathrm{TiO}_{2}$ and CuSCN: analysis of pore filling and IV characteristics," Chemistry of Materials, vol. 14, no. 12, pp. 5023-5029, 2002.

[7] K. Murakoshi, R. Kogure, Y. Wada, and S. Yanagida, "Fabrication of solid-state dye-sensitized $\mathrm{TiO}_{2}$ solar cells combined with polypyrrole," Solar Energy Materials and Solar Cells, vol. 55, no. 1-2, pp. 113-125, 1998.

[8] J. Hagen, W. Schaffrath, P. Otschik et al., "Novel hybrid solar cells consisting of inorganic nanoparticles and an organic hole transport material," Synthetic Metals, vol. 89, no. 3, pp. 215-220, 1997.

[9] D. Wei, P. Andrew, and T. Ryhänen, "Electrochemical photovoltaic cells-review of recent developments," Journal of Chemical Technology and Biotechnology, vol. 85, no. 12, pp. 1547-1552, 2010.

[10] J. Wu, Z. Lan, S. Hao et al., "Progress on the electrolytes for dyesensitized solar cells," Pure and Applied Chemistry, vol. 80, no. 11, pp. 2241-2258, 2008.

[11] B. Li, L. Wang, B. Kang, P. Wang, and Y. Qiu, "Review of recent progress in solid-state dye-sensitized solar cells," Solar Energy Materials and Solar Cells, vol. 90, no. 5, pp. 549-573, 2006.

[12] L. Yang, Z. Zhang, S. Fang, X. Gao, and M. Obata, "Influence of the preparation conditions of $\mathrm{TiO}_{2}$ electrodes on the performance of solid-state dye-sensitized solar cells with $\mathrm{CuI}$ as a hole collector," Solar Energy, vol. 81, no. 6, pp. 717-722, 2007.

[13] E. V. A. Premalal, N. Dematage, G. R. R. A. Kumara et al., "Preparation of structurally modified, conductivity enhancedp-CuSCN and its application in dye-sensitized solid-state solar cells," Journal of Power Sources, vol. 203, pp. 288-296, 2012.

[14] Y. Ni, Z. Jin, K. Yu, Y. Fu, T. Liu, and T. Wang, "Electrochemical deposition characteristics of $\mathrm{p}-\mathrm{CuSCN}$ on $\mathrm{n}-\mathrm{ZnO}$ rod arrays films," Electrochimica Acta, vol. 53, no. 20, pp. 6048-6054, 2008.

[15] C.-Y. Hsu, W.-T. Chen, Y.-C. Chen et al., "Charge transporting enhancement of $\mathrm{NiO}$ photocathodes for p-type dye-sensitized solar cells," Electrochimica Acta, vol. 66, pp. 210-215, 2012.

[16] Y.-M. Lee and C.-H. Lai, "Preparation and characterization of solid $\mathrm{n}-\mathrm{TiO}_{2} / \mathrm{p}-\mathrm{NiO}$ hetrojunction electrodes for all-solid-state dye-sensitized solar cells," Solid-State Electronics, vol. 53, no. 10, pp. 1116-1125, 2009.

[17] J. H. Rhee, Y. H. Lee, P. Bera, and S. I. Seok, "Cu 2 S-deposited mesoporous $\mathrm{NiO}$ photocathode for a solar cell," Chemical Physics Letters, vol. 477, no. 4-6, pp. 345-348, 2009.

[18] M. Song, J. S. Park, Y. H. Kim et al., "Synthesis and characterization of polymer electrolytes containing phenothiazinebased click polymers for dye-sensitized solar cell applications," Macromolecular Research, vol. 19, no. 7, pp. 654-659, 2011.

[19] M.-S. Kang, K.-S. Ahn, and J.-W. Lee, "Quasi-solid-state dyesensitized solar cells employing ternary component polymergel electrolytes," Journal of Power Sources, vol. 180, no. 2, pp. 896-901, 2008.

[20] Powder Diffract. File, JCPDS-ICDD, 12 Campus Boulevard, Newtown Square, PA 19073-3273, USA, 2001.

[21] T. Suriwong, S. Thongtem, and T. Thongtem, "Solid-state synthesis of cubic ZnTe nanocrystals using a microwave plasma," Materials Letters, vol. 63, no. 24-25, pp. 2103-2106, 2009.

[22] Q. Meng, C. Jiang, and S. X. Mao, "Temperature-dependent growth of zinc-blende-structured ZnTe nanostructures," Journal of Crystal Growth, vol. 310, no. 20, pp. 4481-4486, 2008.

[23] S. H. Lee, Y. J. Kim, and J. Park, "Shape evolution of ZnTe nanocrystals: nanoflowers, nanodots, and nanorods," Chemistry of Materials, vol. 19, no. 19, pp. 4670-4675, 2007.

[24] J. Gong, J. Liang, and K. Sumathy, "Review on dye-sensitized solar cells (DSSCs): fundamental concepts and novel materials," Renewable and Sustainable Energy Reviews, vol. 16, pp. 58485860, 2012. 
[25] J. Chen, T. Peng, K. Fan, R. Li, and J. Xia, "Optimization of plastic crystal ionic liquid electrolyte for solid-state dyesensitized solar cell," Electrochimica Acta, vol. 94, pp. 1-6, 2013.

[26] J. E. Benedetti, A. A. Corrêa, M. Carmello, L. C. P. Almeida, A. S. Gonalves, and A. F. Nogueira, "Cross-linked gel polymer electrolyte containing multi-wall carbon nanotubes for application in dye-sensitized solar cells," Journal of Power Sources, vol. 208, pp. 263-270, 2012.

[27] I. Chung, B. Lee, J. He, R. P. H. Chang, and M. G. Kanatzidis, "All-solid-state dye-sensitized solar cells with high efficiency," Nature, vol. 485, pp. 486-490, 2012.

[28] F. Odobel, Y. Pellegrin, E. A. Gibson, A. Hagfeldt, A. L. Smeigh, and L. Hammarström, "Recent advances and future directions to optimize the performances of p-type dye-sensitized solar cells," Coordination Chemistry Reviews, vol. 256, pp. 2414-2423, 2012.

[29] F. Bella and R. Bongiovanni, "Photoinduced polymerization: an innovative, powerful and environmentally friendly technique for the preparation of polymer electrolytes for dye-sensitized solar cells," Journal of Photochemistry and Photobiology C, vol. 16, pp. 1-21, 2013.

[30] N. Khongchareon, S. Choopun, N. Hongsith, A. Gardchareon, S. Phadungdhitidhada, and D. Wongratanaphisan, "Influence of carbon nanotubes in gel electrolyte on photovoltaic performance of $\mathrm{ZnO}$ dye-sensitized solar cells," Electrochimica Acta, vol. 106, pp. 195-200, 2013.

[31] J. H. Kim, Y. S. Chi, and T. J. Kang, "Optimization of quasi-solidstate dye-sensitized photovoltaic fibers using porous polymer electrolyte membranes," Journal of Power Sources, vol. 229, pp. 84-94, 2013.

[32] G. R. A. Kumara, J. K. Tiskumara, C. S. K. Ranasinghe et al., "Efficient solid-state dye-sensitized $\mathrm{n}-\mathrm{ZnO} / \mathrm{D}-358$ dye/p-CuI solar cell," Electrochimica Acta, vol. 94, pp. 34-37, 2013. 

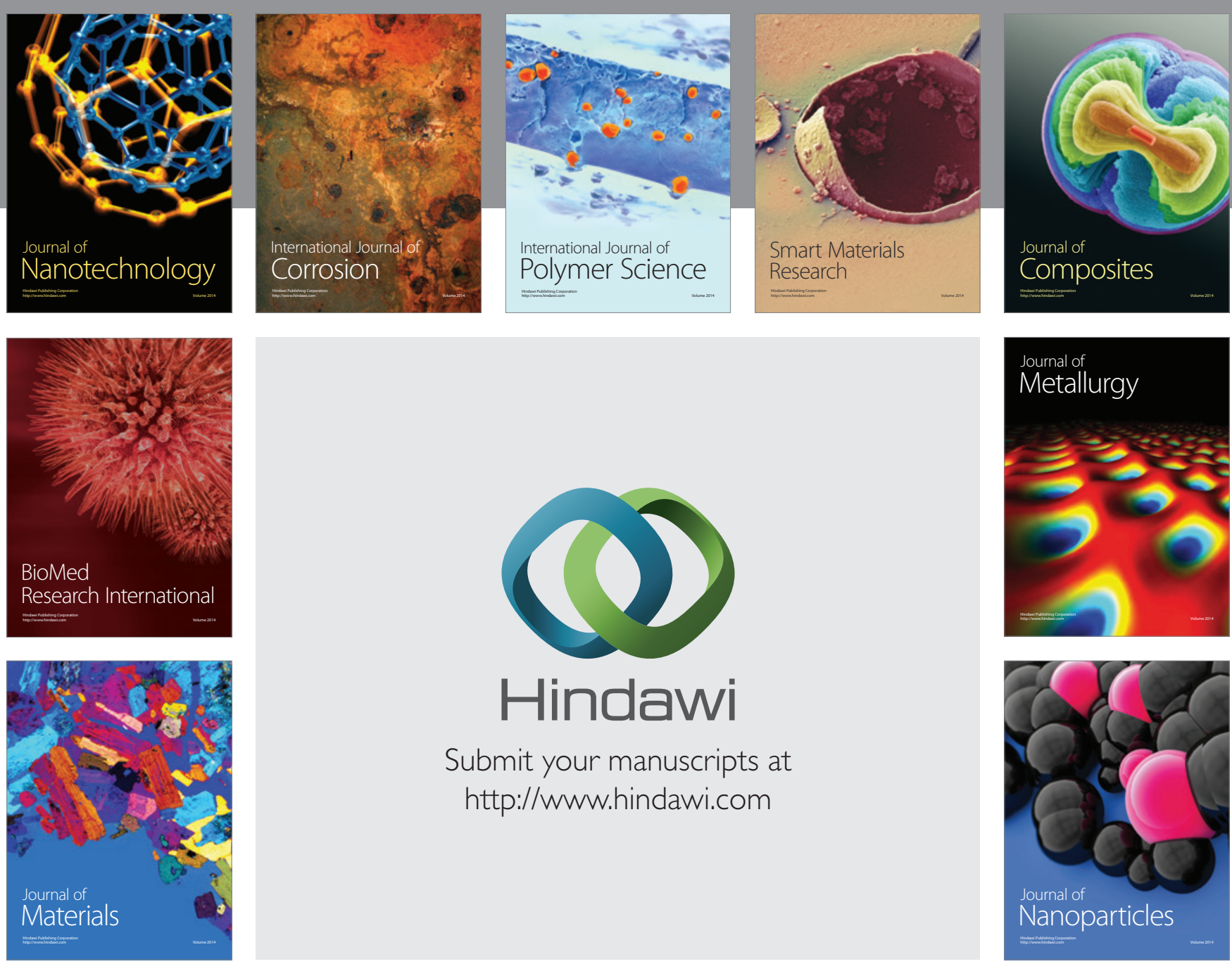

Submit your manuscripts at http://www.hindawi.com
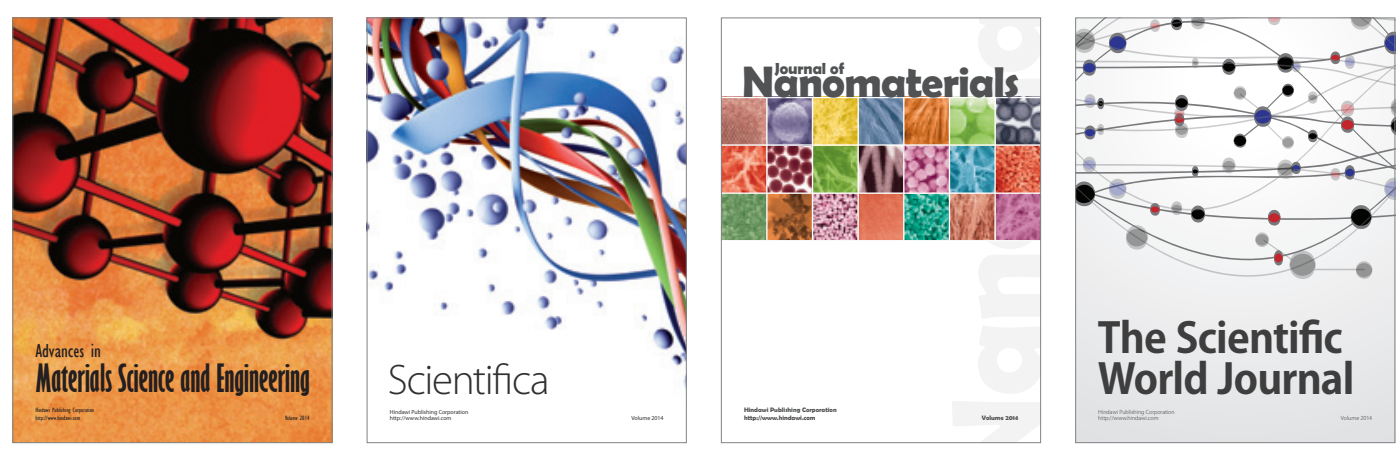

\section{The Scientific World Journal}
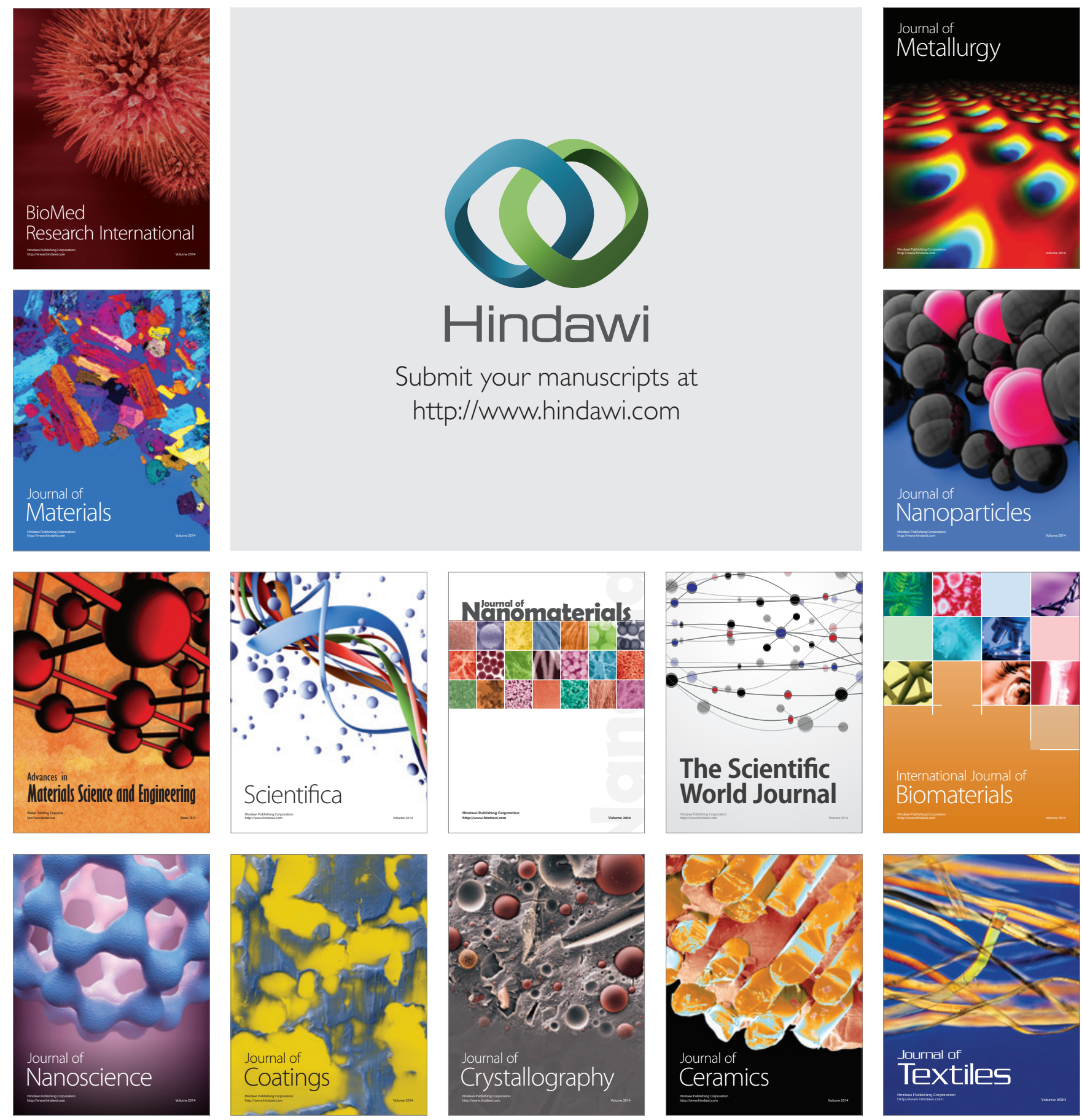